\title{
EVSItalia Database of Broadleaved Temperate Deciduous Forests
}

\author{
Francesco Spada, Emiliano Agrillo \& Marco Massimi
}

\begin{abstract}
A database of phytosociological relevés of Broadleaved Temperate Deciduous Forests of peninsular Italy (Apennines, from Liguria to Calabria regional districts) is presented (EVSItalia Database of Broadleaved Temperate Deciduous Forests, GIVD ID EUIT-011). The data-set aims to store information from published certified phytosociological sources, in order to support ongoing reviews based on larger data-sets for comparative classification of Italian vegetation types. The database stores 1,092 relevés, mostly from beech forests, along an altitudinal gradient. Three beech forest types are identified: between 800 and 1,000/1,100 m.a.s.1., a mixed forest with the presence of $Q$. cerris, Ilex aquifolium, Tilia sp. and Taxus baccata; above 1,100 m a.s.l. until the treeline, a beechdominated forest; below $800 \mathrm{~m}$ a.s.1., relic Fagus forests, in very restricted areas of the Apennines. All the relevés are uploaded to the TURBOVEG software for plot databases. An ArcGis Database related to the TURBOVEG units reports localization information in GPS coordinates, toponym or quadrats (grid of Operational Geographic Units -OGU of the Italian floristic grid). Descriptive records of locations extracted from geographical information systems are also stored. The data model structure allows producing presenceabsence or quantitative matrices for classification of communities and their parametrisation over larger areas by geostatistical analysis. The aims are to explore patterns of similarity among the distribution of different associations (chorological groups of associations, provincialism), patterns of geographic changes in community distribution along topographical gradients and to test changes in the physical scenario of selected individual communities along geographical gradients. A different insight into the patterns of synonymy and reassessment among syntaxa on the basis of a geographical treatise is expected as well.
\end{abstract}

Keywords: Italian vegetation vatabase; TURBOVEG.

GIVD Database ID: EU-IT-011

Last update: 2012-07-09

\section{EVSItalia Database Broadleaved Temperate Deciduous Forests}

Scope: The data-set aims to store information from published/certified phytosociological sources in order to support ongoing reviews based on larger data-sets for comparative classification of Italian vegetation types.

Status: completed and continuing

Period: $1960-2009$

Database manager(s): Emiliano Agrillo (emiliano.agrillo@uniroma1.it)

Owner: [NA]

Web address: [NA]

Availability: according to a specific agreement

Online upload: no Online search: no

Database format(s): TURBOVEG, ArcGis database

Export format(s): TURBOVEG, ArcGis database

Publication: [NA]

Plot type(s): normal plots

Non-overlapping plots: 1,092

Total plot observations: 1,092

Plot-size range: $10-2000 \mathrm{~m}^{2}$

Countries: IT: $75.0 \%$

Forest: [NA] — Non-forest: [NA]

Guilds: all vascular plants: $100 \%$; bryophytes (terricolous or aquatic): $2 \%$

Environmental data: [NA]

Performance measure(s): [NA]

Geographic localisation: [NA]

Sampling periods: [NA]

Information as of 2012-07-12; further details and future updates available from http://www.givd.info/ID/EU-IT-011

Francesco Spada (francesco.spada@uniroma1.it), Emiliano Agrillo* (emiliano.agrillo@uniroma1.it), Marco Massimi (marco.massimi@uniroma1.it)

Department of Environmental Biology, Sapienza University of Roma, Rome, ITALY

*Corresponding author 